\title{
FLNC wt Allele
}

National Cancer Institute

\section{Source}

National Cancer Institute. FLNC wt Allele. NCI Thesaurus. Code C88952.

Human FLNC wild-type allele is located within 7q32-q35 and is approximately 29 kb in length. This allele, which encodes filamin- $C$ protein, is involved in the modulation of both myogenesis and muscle fiber structure. Mutation of the gene is associated with filamenopathy. 